\title{
BONUS DEMOGRAFI DI INDONESIA
}

\author{
Oleh
}

\author{
Achmad Nur Sutikno
}

Institut Pemerintahan Dalam Negeri

achmad.rayhan20@gmail.com

\begin{abstract}
Demographic Dividend is a phenomenon of civilization of population in a country where, there is an explosion of the number of people of productive age that can be the basic capital in development. The problems faced by the Indonesian people are how to handle this demographic dividend because if it is not handled properly it will cause huge losses to Indonesia, thus the demographic dividend must be treated well and comprehensively so as not to cause disasters in the future. the explosion of population will impact on all other aspects in various fields, namely population, health, welfare, economy, and others.

The research method that I use is using literature studies with descriptive-qualitative analysis methods based on library research. While the purpose of this study is to uncover facts, circumstances, phenomena, variables and circumstances that occur when the research is running and present what it is. Research results Demographic Dividend which is a golden age for Indonesia, but this dividend can turn into a big disaster if this golden generation is not well prepared. The number of productive age population will reach its peak in 2020-2035 when the figure reaches $70 \%$. The current population of Indonesia at productive age between 15-64 years is more than the unproductive age of children aged 0-14 years and parents aged 65 years and over. The big challenge facing education is how to strive so that the abundant productive age human resources can be transformed into human resources that have the competence and skills through education so as not to become a burden. This is a positive influence on the Indonesian nation. Because, with the increasingly abundant Human Resources of productive age, the production workforce will be more and more.
\end{abstract}

Keywords: demographic dividend, population.

\begin{abstract}
Abstrak
$\mathrm{B}$ onus Demografi merupakan fenomena peradaban kependudukan suatu negara di mana, terjadi ledakan jumlah penduduk usia produktif yang dapat menjadi modal dasar dalam pembangunan. Permasalahan yang dihadapi bangsa Indonesia bagaimana penanganan Bonus Demografi ini sebab apabila tidak ditangani dengan baik akan menmbulkan kerugian besar bagi Indonesia, dengan demikian Bonus Demografi harus mendapat penanganan yang baik dan komprehensif agar tidak menimbulkan bencana di kemudian hari. ledakan jumlah penduduk akan berimbas pada segala aspek lain dalam berbagai bidang yaitu kependudukan, kesehatan, kesejahteraan, perekonomian, dan lain-lain.

Metode Penelitian yang penulis gunakan yaitu menggunakan studi literatur dengan metode analisis deskriptif-kualitatif dengan berbasiskan kajian kepustakaan (library research). Sedangkan Tujuan dari penelitian ini adalah mengungkap fakta, keadaan, fenomena, variabel dan keadaan yang terjadi saat penelitian berjalan dan menyajikan apa adanya. Hasil penelitian
\end{abstract}


Bonus Demografi yang merupakan masa emas bagi Indonesia, Namun bonus ini bisa berubah menjadi bencana besar apabila tidak dipersiapkan generasi emas ini dengan baik. Jumlah penduduk usia produktif akan mencapai puncaknya pada 2020-2035 pada saat angkanya mencapai 70\%. Jumlah penduduk Indonesia saat ini pada usia produktif antara 15-64 tahun lebih banyak dari usia tidak produktif anak-anak berusia 0-14 tahun dan orang tua berusia 65 tahun ke atas. Tantangan besar yang dihadapi pendidikan adalah bagaimana mengupayakan agar sumber daya manusia usia produktif yang melimpah ini dapat ditransformasikan menjadi sumber daya manusia yang memiliki kompetensi dan keterampilan melalui pendidikan agar tidak menjadi beban. Hal tersebut merupakan pengaruh positif bagi bangsa Indonesia. Karena, dengan semakin melimpahnya Sumber Daya Manusia usia produktif, maka tenaga kerja produksi semakin banyak.

Kata kunci: Bonus Demografi, kependudukan.

\section{PENDAHULUAN}

asa transisi demografi Bangsa Indonesia

$\mathrm{M}^{2}$

yang sangat menguntungkan ketika penduduk usia produktif (1564 tahun) mengalami jumlah terbesar dibandingkan dengan proporsi penduduk usia nonproduktif. Karena proporsi penduduk ini, terdapat keuntungan yang bisa dinikmati oleh suatu negara sebagai batu loncatan untuk memajukan negara yang bersangkutan. Di dalam ilmu demografi, kondisi ini disebut Bonus Demografi. dan Indonesia diprediksi akan mengalami Bonus Demografi pada 20202035 yang akan datang. Dalam Seminar masalah kependudukan di

Indonesia yang dilaksanakan di Fakultas Kedokteran Universitas Indonesia yang dipaparkan oleh Surya Chandra, dari anggota DPR Komisi IX, bahwa jumlah usia angkatan kerja (15-64 tahun) pada 2020-2035 akan mencapai 70 persen, sedangkan 30 persen adalah penduduk dengan usia nonproduktif (di bawah 15 tahun dan di atas 65 tahun). Bila dilihat dari jumlahnya, penduduk usia produktif mencapai sekitar 180 juta, sementara penduduk nonproduktif hanya 60 juta.

Bonus Demografi ini tentu akan membawa dampak sosial-ekonomi. Salah satunya menyebabkan tingkat penduduk produktif yang menanggung penduduk nonproduktif akan sangat rendah, diperkirakan mencapai 44 per 100 penduduk produktif. Hal ini sejalan dengan laporan PBB, yang menyatakan bahwa dibandingkan dengan negara Asia lainnya, angka ketergantungan penduduk Indonesia akan terus menurun sampai 2020.

$$
\text { Dengan adanya } \begin{array}{r}
\text { kondisi } \\
\text { Bonus }
\end{array}
$$

Demografi, tentu bisa menjadi peluang bagi Indonesia untuk memajukan kesejahteraan serta memakmurkan masyarakat, apabila masyarakat usia produktif memiliki kualitas sumber daya manusia yang dapat menunjang serta memberikan kontribusi terhadap pembangunan negara. Apabila suatu negara gagal dalam memanfaatkan Bonus Demografi maka, jelas akan terjadi kerugian sangat besar bagi negara yang bersangkutan khususnya Indonesia. untuk meraih manfaat dari Bonus Demografi, diperlukan usaha bersama dari seluruh lapisan masyarakat dan lembaga terkait serta pemerintah sebagai agent of development yang ada di suatu negara agar manfaat Bonus Demografi ini menjadi semakin kuat.

Salah satu keberhasilan pembangunan bangsa ditentukan oleh kualitas sumber daya manusia. Hal ini selaras dengan Nawacita kelima Presiden Jokowi yang menyatakan "peningkatan kesejahteraan rakyat melalui peningkatan kualitas hidup manusia

Indonesia". Melalui Nawacita kelima tersebut, terlihat komitmen pemerintah yang tinggi terhadap pembangunan manusia. Pada 2045, atau tiga puluh tahun dari sekarang, hampir 60 persen penduduk Indonesia berusia di bawah 30 tahun. Dapat dikatakan, Indonesia akan mendapatkan Bonus Demografi. 
Artinya, secara jumlah akan ada lebih banyak penduduk usia produktif dan berpendidikan dibanding dengan periode sebelumnya. Bonus Demografi ini bisa memberikan sinyal yang baik, hal tersebut apabila tidak dimanfaatkan akan menjadi disaster, dan jika tidak diinvestasi dengan kesehatan, pendidikan, dan karakter, penduduk usia produktif yang banyak akan menjadi liability, bukan aset. Bonus Demografi salah satunya disebabkan oleh laju pertumbuhan.

Fenomena Bonus Demografi atau biasa disebut Ledakan Penduduk dicirikan dengan jumlah penduduk usia produktif jauh lebih banyak dibanding jumlah penduduk usia nonproduktif. Indonesia diprediksi akan mencapai titik puncak Bonus Demografi pada 2020 dengan jumlah penduduk mencapai 280 juta. Dari data tersebut, jumlah penduduk usia produktif lebih banyak 1,9\% dibandingkan jumlah penduduk usia nonproduktif.

Pertumbuhan penduduk Indonesia saat ini sudah sangat pesat yang dibuktikan dengan padatnya penduduk daerah/kota dan semakin berkurangnya lahan pertanian. Menurut data Badan Pusat Statistik (BPS) dalam Sensus Penduduk 2010, penduduk Indonesia mencapai 237.641.326 juta jiwa dengan kepadatan 4,58\%. Dari pernyataan sangat jelas bahwa tingkat fertilitas, mortalitas, migrasi dan mobilitas sosial bangsa Indonesia setiap tahun semakin meningkat. Seperti fenomena kependudukan yang berkembang akhir-akhir ini bangsa Indonesia akan mendapatkan bonus yang disebut Bonus Demografi di mana kondisi tersebut proporsi angka ketergantungan menurun drastis karena jumlah penduduk usia produktif lebih banyak dari pada penduduk usia nonproduktif. Menurut Adietomo (2005: 7) menyatakan bahwa rasio ketergantungan Indonesia menurun dari 86 per 100 penduduk usia kerja pada 1971 menjadi 50 per 100 tahun 2000.
Rasio ketergantungan penduduk Indonesia telah menurun sekitar 55 pada 2000 dan terus menurun sampai angka terendah pada 2020-2030 yang berkisar sekitar 45 per 100 penduduk yang artinya tiap-tiap 100 orang penduduk usia produktif hanya menanggung 45 penduduk tidak produktif. Inilah yang disebut dengan Bonus Demografi yaitu jendela kesempatan yang dapat digunakan untuk meningkatkan pertumbuhan ekonomi sekaligus peningkatan kesejahteraan bangsa Indonesia. Karena pada dasarnya ruang lingkup kajian demografi tidak hanya terbatas pada masalah statistik kependudukan saja, tetapi pengaruhnya terhadap aspekaspek kehidupan lainnya. Kemudian Pollard dkk. (1984: 2) menyatakan sebagai berikut.

"Subjek permasalahan demografi pada hakikatnya lebih dititikberatkan kepada studi kuantitatif mengenai berbagai faktor seperti fertilitas, mortalitas, maupun migrasi yang selalu memengaruhi penduduk secara kontinu, serta menentukan jumlah maupun pertumbuhan penduduk yang tidak dapat diragukan lagi bahwa perubahan dalam jumlah maupun komposisi penduduk akan memberikan pengaruh sosial, ekonomis, politis maupun lainnya terhadap penduduk yang tinggal di suatu negara".

Pemerataan pembangunan ekonomi dan sosial merupakan syarat untuk meredakan laju pertumbuhan penduduk dan mengantarkan suatu negara untuk lebih maju. Dari hal tersebut di atas bahwa penduduk menjadi independent variabel pertumbuhan penduduk dan pembangunan ekonomi. Sedangkan kemajuan suatu bangsa sangat ditentukan oleh pertumbuhan ekonomi negara. teori tentang kependudukan terhadap pembangunan menjadi sangat penting untuk kemajuan suatu bangsa, Kesempatan besar yang akan diperoleh Indonesia dalam Bonus Demografi akan menjadi kesempatan yang siasia jika tidak bisa memanfaatkan momentum ini untuk membawa Negara Indonesia menjadi lebih maju dari sebelumnya. Bonus Demografi 
merupakan suatu kesempatan yang sangat langka, karena tidak setiap tahun dan tidak setiap negara akan memperoleh bonus ini. Dengan demikian Bonus Demografi menjadi suatu kesempatan yang berguna dalam peranannya untuk memajukan bangsa

Indonesia, perlu adanya pemanfaatan secara optimal dengan perencanaan pembangunan yang berwawasan kependudukan karena penduduk sebagai aspek utama dalam proses pembangunan suatu bangsa. Seperti pendapat yang diungkapkan oleh Adam Smith dalam Darwis bahwa sesungguhnya ada hubungan yang harmonis dan alami antara pertumbuhan penduduk dan pertumbuhan ekonomi. Sehingga untuk mempersiapkan pemanfaatan peluang itu perlu adanya kebijakan peningkatan kualitas sumber daya manusia dan perluasan lapangan kerja mulai dari sekarang agar keinginan untuk memajukan bangsa Indonesia dengan memanfaatkan Bonus Demografi dapat terwujud dengan nyata.

\section{TINJAUAN PUSTAKA}

\section{Demografi}

Kata demografi berasal dari bahasa Yunani yang berarti "demos" adalah rakyat atau penduduk dan "grafein" adalah menulis. Jadi demografi adalah tulisantulisan atau karangan-karangan mengenai rakyat atau penduduk. Istilah ini dipakai untuk pertama kalinya oleh Achille Guillard dalam karangannya yang berjudul Elements de Statistique Humaine on Demographic Compares pada 1885. Menurut Donald J. Boguedi dalam bukunya yang berjudul Principles of Demoraphy definisi Demografi adalah sebagai berikut. "Demografi adalah ilmu yang mempelajari secara statistik dan matematik tentang besar, komposisi dan distribusi penduduk dan perubahanperubahannya sepanjang masa melalui bekerjanya lima komponen demografi yaitu kelahiran (fertilitas), kematian (mortalitas), perkawinan, migrasi, dan mobilitas sosial".
Demografi dapat dikatakan juga sebagai sebuah ilmu interdisipliner karena relasinya dengan banyak disiplin ilmu akademis lainnya seperti matematika, statistika, biologi, kedokteran, geografi, sosiologi, ekonomi, dan psikologi. Banyak demografer mengikuti pelatihan di bidang ilmu lainnya sebelum memilih spesialisasi demografi. Sebagai contoh bahwa demografi berhubungan dengan ilmu lain dengan membayangkan sebuah studi tentang keluarga. Para demografer sangat tertarik dengan keluarga karena peristiwa demografi dapat memengaruhi ukuran dan komposisinya. Seorang ahli sejarah dalam demografer sejarah, sangat mungkin memperhatikan keluarga dari masa lampau, dengan usia perkawinan dan komposisi serta ukuran dari satu rumah tangga di masa lalu. Karena keluarga adalah unit paling dasar dalam aktivitas sosial, ahli sosiologi dan antropologi juga tertarik pada status, peranan, jaringan dan pembuat keputusan di dalam keluarga serta pranata yang ada di dalam keluarga tersebut (lihat Caldwell et al. 1988 ; Hawthorn 1970; Nag 1973).

\section{Kependudukan}

Kependudukan adalah sebuah ilmu tentang makhluk hidup atau manusia yang terdapat dalam sebuah rumpun kehidupan sehingga dapat Melakukan penyebaran dan perkembangan atau populasi dalam mata rantai kehidupan. Teori kependudukan dibagi dalam tiga kelompok besar: (1) aliran Malthusian yang dipelopori oleh Thomas Robert Malthus; (2) aliran Marxist yang dipelopori oleh Karl Marx dan Friedrich Engels; dan (3) 3. Aliran Neo-Malthusian oleh Garreth Hardin dan Paul Ehrlich (Mantra, 2008). Menurut aliran Malthusian: terjadi ke tidak seimbangan antara pertumbuhan penduduk dengan pertumbuhan makanan, dalam hal ini pertumbuhan penduduk berjalan berdasarkan deret ukur, sedangkan pertumbuhan/pertambahan berdasarkan deret hitung. Oleh karena itu, pertumbuhan 
penduduk harus dibatasi. Pembatasan jumlah penduduk dapat dilaksanakan dengan dua cara, yaitu preventive dan positive check.

Menurut kalangan sosialis awal dalam masyarakat yang sudah direorganisasikan maka pertumbuhan penduduk dapat dicegah oleh peningkatan produksi, maupun oleh tata kehidupan sosial yang lebih baik. Nitti (1894) dalam Munir \& Budiarto 1986 mengemukakan bahwa setiap peningkatan kondisi ekonomi kelas pekerja akan menyebabkan tingkat kelahiran menurun, dan masalah kependudukan dapat diatasi dengan melakukan reorganisasi terhadap masyarakat agar sebab-sebab ketidaksamaan dapat dihilangkan (Munir \& Budiarto, 1986).

Dalam konteks historis materialism yang lebih luas, marx dan engels memang tidak menyusun formulasi tentang teori kependudukan semata-mata, tetapi menyusun seperangkat prinsip-prinsip dasar yang mereka anggap sebagai faktorfaktor yang dapat memengaruhi kependudukan serta korelasi ekonomi dan sosialnya. Marx menyatakan bahwa tidak mungkin terdapat hukum kependudukan yang alamiah atau yang universal; pertumbuhan penduduk akan lebih ditentukan oleh kondisi-kondisi sosial dan ekonomis yang memengaruhi berbagai masyarakat. Menurut Marx, perbedaan mortalitas dan fertilitas, baik di dalam kelas sosial maupun di dalam kelas pekerja, akan senantiasa dibentuk oleh posisi sosial, tingkat kehidupan (suatu istilah modern untuk jumlah sarana-sarana kehidupan), kondisi sosial maupun faktor-faktor sosial lainnya. (Munir \& Budiarto, 1986).

Studi kependudukan merupakan studi yang membahas tentang hubungan antara faktor-faktor perubahan penduduk dan faktor-faktor pembangunan. T. Romlinson (1965) mengatakan bahwa studi kependudukan menerangkan informasi dasar tentang distribusi penduduk, karakteristik dan perubahanperubahannya, serta menerangkan faktor penyebab perubahan tersebut dan menganalisis segala konsekuensi yang mungkin sekali terjadi di masa depan sebagai hasil perubahan tersebut.

Menurut Mantra (2000) mengatakan bahwa studi kependudukan lebih luas dari kajian demografi murni, karena di dalam memahami struktur dan proses kependudukan di suatu wilayah, faktor-faktor non demografis ikut dilibatkan, misalnya dalam memahami fertilitas di suatu daerah tidak hanya cukup diketahui trend pasangan usia subur tetapi juga faktor sosial, ekonomi dan budaya yang ada di daerah tersebut. Dengan kata lain studi kependudukan lebih bersifat interdisipliner dan lebih mencakup tentang ilmu sosial, ekonomi, budaya, lingkungan, politik, dan biologi. Banyak demografer yang lebih menyukai pendekatan studi kependudukan di mana hubungan antara variabel-variabel demografis dan nondemografis diperhitungkan. Para demografer sangat tertarik dengan efek dari variabel nondemografis terhadap variabel demografis, contohnya bagaimana perubahan dari pendapatan atau tingkat pendidikan keluarga dapat memengaruhi kelahiran dan kematian.

Beberapa demografer justru tertarik kepada hal sebaliknya; apakah variabel demografis akan menyebabkan perubahan pada variabel nondemografis. Hal ini juga menjadi perhatian beberapa ahli pada disiplin ilmu berbeda. Misalnya, ketika suatu populasi memiliki proporsi lansia yang besar, pola pemilihan umum bisa jadi berbeda, karena para lansia lebih memilih partai politik tradisional yang sudah ada sejak lama. Jika terjadi hal seperti itu, maka topik ini adalah kewenangan ahli politik, bukan demografer lagi. Analisis penduduk merupakan analisis yang dimulai "dari rahim ke liang kubur" (from the womb to the tomb) karena analisis penduduk pada seluruh siklus kehidupan 
manusia sejak dari kandungan sampai meninggal.

Dari hal tersebut di atas terdapat struktur penduduk selalu berubah-ubah, perubahan tersebut disebabkan karena prosres demografi yaitu kelahiran (fertilitas), kematian (mortalitas), dan migrasi penduduk. Struktur penduduk merupakan aspek yang statis, yang menggambarkan penduduk dari hasil sensus penduduk pada hari sensus tersebut. Data yang didapat pada hari sensus dijadikan sebagai basis perhitungan penduduk. Setelah hari sensus penduduk tersebut dilakukan maka struktur penduduk akan berubah dari basis penduduk sebelumnya. Unsur-unsur yang dinamis yang terdiri dari kelahiran, kematian, dan migrasi. Proses perubahan tersebut disebut pula dengan proses yang dinamis. Masalah kependudukan sangat memengaruhi kesejahteraan dan perkembangan suatu daerah dan negara.

Masalah kependudukan di Indonesia dikategorikan sebagai suatu masalah nasional yang besar dan memerlukan pemecahan segera. Hal ini mencakup lima masalah pokok yang terkait satu sama lainnya, yaitu: 1) Jumlah penduduk yang tinggi 2) Tingkat pertumbuhan yang tinggi 3) Penyebaran penduduk yang tidak merata 4) Komposisi umur penduduk yang timpang 5) Masalah mobilitas penduduk. Paket masalah kependudukan ini telah menjadi induk dari berbagai masalah lain. Apabila tidak segera ditanggulangi, tidak mustahil akan mendatangkan efek yang lebih parah lagi dan dapat melumpuhkan pembangunan nasional.

\section{Bonus Demografi}

Bonus Demografi atau bisa disebut Ledakan Penduduk, Fenomena Bonus Demografi dicirikan dengan jumlah penduduk usia produktif jauh lebih banyak dibanding jumlah penduduk usia nonproduktif. Menurut Wongboonsin (2003) bahwa Bonus Demografi (demographic deviden) adalah suatu keuntungan ekonomis yang disebabkan menurunnya rasio ketergantungan jumlah penduduk, sebagai hasil fertilitas jangka panjang.

Sementara itu, Tifatul Sembiring (Kominfo, 2014), mengemukakan pengertian Bonus Demografi adalah suatu keadaan penduduk yang menguntungkan, karena jumlah penduduk didominasi oleh masyarakat berusia produktif. Selanjutnya, BKKBN (2013), memberikan pengertian bahwa Bonus Demografi adalah keuntungan jumlah penduduk yang dinikmati negara. Sebagai akibat dari besarnya proporsi penduduk produktif yang ada dalam masyarakat.

Wikipedia (2016) memberikan pandangan Bonus Demografi sebagai fenomena penting yang di alami Indonesia karena suatu kondisi penduduknya yang lebih besar di usia produktif dibandingkan dengan usia tidak produktif. Selanjutnya Kamus Besar Bahasa Indonesia (2016), menyatakan bahwa Bonus Demografi adalah istilah dalam kependudukan yang menggambarkan jumlah usia produktif lebih besar dari pada usia tidak produktif.

Adapun menurut Jimmy Ginting (2016), mengatakan bahwa Bonus Demografi sebagai ledakan penduduk usia produktif yang akan terjadi di Indonesia pada 2020 2035 dan Ray (1998), menyatakan dalam bukunya yang berjudul Economic Devolovement bahwa Bonus Demografi yang terjadi ledakan penduduk yang berdampak kepada pembangunan ekonomi terhadap penduduk, Akan tetapi perubahan penduduk mempunyai implikasi terhadap pembangunan perekonomian.

\section{METODE PENELITIAN}

Kajian ini merupakan studi literatur yang menggunakan metode analisis deskriptif kualitatif berbasis kajian kepustakaan (library research). Analisis deskriptif kualitatif merupakan analisis yang didasarkan pada pemetaan permasalahan yang terdapat dalam variabel atau kasus yang sedang dikaji dan 
kemudian dicari titik korelasinya. Korelasi tersebut bisa menjadi mengonfirmasi, menolak, dan seimbang berdasarkan pada data dan informasi yang berhasil dilakukan oleh peneliti. Sedangkan studi kepustakaan merupakan instrument penelitian dengan mengumpulkan berbagai macam literature baik dalam bentuk jurnal, buku, prosiding, working paper, maupun sumber data lainnya yang memiliki keterkaitan dengan permasalahan dalam kajian ini. Adapun tahapan kegiatan dalam menganalisis data dan dokumen dalam kajian ini adalah sebagai berikut.

1) Melakukan studi pendahuluan dengan meneliti kajian-kajian penelitian terdahulu yang membahas mengenai pengangguran dan Bonus Demografi di Indonesia

2) Mengumpulkan literatur relavan sesuai dengan fokus permasalahan yang diangkat sebagai tema utama dalam kajian ini.

3) Menganalisis secara kritis berbagai sumber literatur tersebut untuk mendapatkan pemahaman mendasar mengenai korelasi antarstudi dan variabel yang diteliti

4) Menulis hasil kajian berdasarkan argumentasi analisis dari berbagai data dan kajian literatur.

5) Merumuskan rekomendasi berdasarkan argumentasi analisis dari berbagai data dan kajian literature.

\section{PEMBAHASAN}

\section{Bonus Demografi}

Bonus Demografi merupakan salah satu perubahan dinamika demografi yang terjadi karena adanya perubahan struktur penduduk menurut umur. Fenomena transisi demografi ini terjadi karena berkurangnya angka kelahiran yang dibarengi oleh tingginya angka kematian dalam jangka panjang. Pada saat terjadi penurunan angka kelahiran dalam jangka panjang, akan berdampak pada pengurangan jumlah penduduk berusia muda ( $<15$ tahun), akan tetapi di satu sisi jumlah penduduk usia produktif $(15-64$ tahun) akan meningkat secara drastis sebagai akibat angka kelahiran yang tinggi di masa lalu. Di sisi lain jumlah penduduk dengan umur di atas 64 tahun akan meningkat secara perlahan dan kemudian meningkat cepat akibat terjadinya peningkatan usia harapan hidup. Pada saat jumlah penduduk usia produktif jauh melebihi jumlah penduduk usia nonproduktif (kurang dari 15 tahun dan di atas 64 tahun) ini lah yang disebut dengan kondisi Bonus Demografi (Rusli, Toersilaningsih, Meirida, Kurniawan, \& Setiawan, 2015)

Parameter yang digunakan dalam menilai fenomena Bonus Demografi adalah Dependency Ratio atau Rasio Ketergantungan, yaitu merupakan rasio yang menggambarkan perbandingan antara jumlah penduduk usia nonproduktif (kurang dari 15 tahun dan di atas 64 tahun) dan penduduk usia produktif (15 - 64 tahun). Angka Rasio Ketergantungan ini menunjukkan beban tanggungan penduduk usia produktif terhadap penduduk usia nonproduktif. Pada saat angka rasio ketergantungan rendah, kondisi ini memperlihatkan bahwa penduduk usia produktif hanya menanggung sedikit penduduk usia nonproduktif.

Angka rasio ketergantungan yang rendah akan berimplikasi pada perekonomian negara yang dapat dijadikan sebagai sebuah kesempatan untuk meningkatkan produktivitas sebuah negara. Kondisi ini dapat menjadi sumber pertumbuhan ekonomi melalui pemanfaatan sumber daya manusia yang produktif yang akan mampu menghasilkan pendapatan untuk memenuhi kebutuhan konsumsi dan meningkatkan tabungan mereka yang pada akhirnya dapat dimobilisasi menjadi investasi (Maryati, 2015). Jadi teori Bonus Demografi pada 
dasarnya merupakan sebuah teori yang menghubungkan antara dinamika kependudukan dengan ekonomi. Semakin sedikit jumlah usia nonproduktif yang harus ditanggung oleh penduduk usia produktif akan berdampak pada pertumbuhan ekonomi yang lebih baik. Idealnya pertumbuhan ekonomi secara maksimal akan terjadi pada saat Rasio Ketergantungan berada di bawah angka 50 . Kondisi ini juga disebut sebagai the window of opportunity (jendela kesempatan) (Kominfo, 2015).

Adioetomo (2005) menyatakan bahwa perubahan dinamika demografi di mana tingginya pertumbuhan penduduk usia kerja akan memengaruhi Gross Domestic Product per kapita sebuah negara yang juga akan berdampak terhadap:

1. Jumlah penduduk usia kerja yang yang tinggi dan dapat diserap oleh pasar kerja akan meningkatkan total output;

2. Akan meningkatkan tabungan masyarakat;

3. Tersedianya sumber daya manusia dalam proses pembangunan ekonomi Kondisi ini hanya akan terjadi sehingga Bonus Demografi betul-betul dapat dimanfaatkan jika sebuah negara memenuhi beberapa prasyarat, yaitu:

1) Pertambahan penduduk usia kerja dibarengi oleh peningkatan kualitas sumber daya manusia baik dari segi kesehatan maupun pendidikan dan keterampilan serta serta peningkatan soft skill sehingga mereka memiliki daya saing secara global.

2) Penduduk usia kerja dapat diserap oleh pasar kerja yang tersedia

3) Tersedianya lapangan kerja yang dapat menyerap tenaga kerja yang tersedia Jika prasyarat di atas tidak dapat terpenuhi yang akan terjadi adalah kebalikan dari Bonus Demografi (Demographic Dividend) yaitu beban demografi (Demographic
Burden), di mana banyaknya jumlah penduduk produktif yang tidak dapat terserap oleh pasar kerja akan menjadi beban ekonomi sebuah Negara. Pada kondisi ini tingkat pengangguran akan tinggi, sehingga penduduk usia kerja yang tidak memiliki pekerjaan akan menjadi beban bagi penduduk yang bekerja.

Setiap negara hanya akan merasakan satu kali Bonus Demografi yang hanya akan terjadi selama satu atau dua dekade saja. Hal ini disebabkan karena seiring dengan berjalannya waktu, penduduk usia produktif akan bertransformasi menjadi penduduk usia nonproduktif dan jumlahnya akan terus bertambah. Hal ini akan berimplikasi pada rasio beban ketergantungan yang akan meningkat dengan cepat. Beberapa negara di dunia telah mampu memaksimalkan Bonus Demografi yang mereka miliki sehingga saat ini mereka muncul sebagai kekuatan ekonomi baru di dunia seperti Korea Selatan, Taiwan, dan Singapura.

Semenjak 2012, Indonesia juga telah memasuki masa Bonus Demografi. Transisi demografi ini terindikasi dari hasil Sensus Penduduk 2000 yang menunjukkan fakta signifikan tentang keberhasilan program Keluarga Berencana yang dilaksanakan pada masa lalu. Fakta yang nampak dari Sensus Penduduk 2010 memperlihatkan bahwa penduduk berusia di bawah 15 tahun hampir tidak bertambah; di mana pada periode 1970-1980-an jumlahnya sekitar 60 juta dan hingga akhir 2000 penduduk dalam kelompok usia ini hanya meningkat menjadi 63-65 juta jiwa. Sebaliknya, penduduk usia 15 - 64 tahun pada 1970 jumlahnya mencapai 63- 65 juta dan telah berkembang menjadi lebih dari 133 - 135 juta, atau mengalami kenaikan dua kali lipat selama 30 tahun (Maryati, 2015).

Selanjutnya Maryati memaparkan, jika dilihat dari ratio dependency, tampak bahwa tingkat ketergantungan penduduk Indonesia 


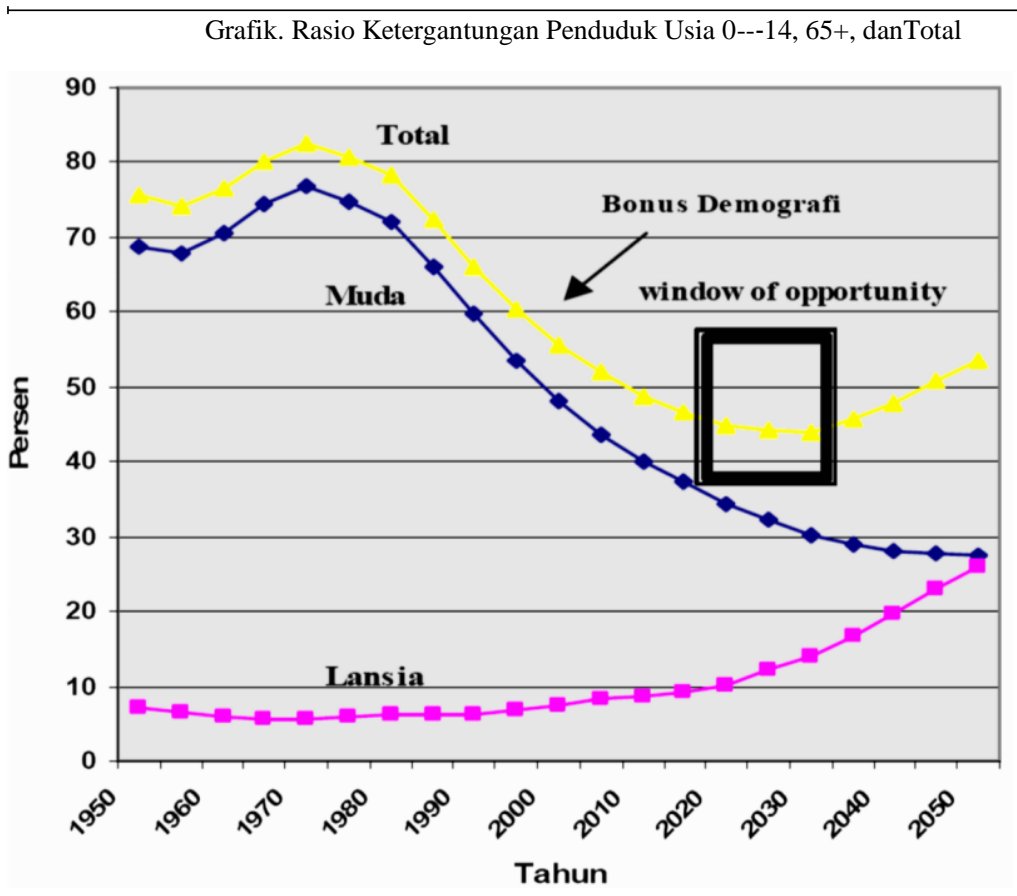

\section{Gambar 1}

Grafik. Rasio Ketergantungan Penduduk

Usia 0---14 , 65+, dan Total

Sumber: Adioetomo (2005:

memperlihatkan trend yang menurun, di mana pada 1970an nilai dependency ratio Indonesia berkisar antara 85-90 per 100 dan pada 2000 menurun hingga ke level 5455 per 100. Hasil Sensus Penduduk 2010 juga memperlihatkan proporsi penduduk usia produktif yang besar di mana mencapai 66 persen dari total penduduk Indonesia.

Sedangkan jumlah penduduk usia muda (1524 tahun) hanya 26,8 persen atau 64 juta jiwa.

Besarnya jumlah penduduk usia produktif tersebut menyebabkan semakin kecilnya nilai angka ketergantungan menjadi 51. Hal ini berarti 100 penduduk usia produktif menanggung 51 orang penduduk tak produktif. Menurut United Nations (PBB) transisi demografi yang terjadi pada beberapa dekade terakhir di Indonesia akan membuka peluang bagi Indonesia untuk menikmati Bonus Demografi (demographic devident) pada periode 2020-2035.

\section{Tabel 1}

Dependency Ratio menurut Provinsi (2010-2035)

$$
\text { Provinsi }
$$

Tahun

\begin{tabular}{|l|l|l|l|l|l|l|}
\cline { 2 - 6 } & $\mathbf{2 0 1 0}$ & $\mathbf{2 0 1 5}$ & $\mathbf{2 0 2 0}$ & $\mathbf{2 0 2 5}$ & $\mathbf{2 0 3 0}$ & $\mathbf{2 0 3 5}$ \\
\hline Aceh & 56,3 & 54,8 & 53,6 & 50,8 & 47,9 & 45,8 \\
\hline Sumatera Utara & 58,0 & 56,3 & 55,3 & 53,6 & 51,7 & 50,8 \\
\hline Sumatera Barat & 57,7 & 55,8 & 54,8 & 53,6 & 51,7 & 50,6 \\
\hline Riau & 54,1 & 51,5 & 49,7 & 48,4 & 47,1 & 46,6 \\
\hline Jambi & 50,8 & 47,3 & 44,5 & 43,3 & 42,7 & 42,7 \\
\hline Sumatera Selatan & 51,3 & 49,7 & 48,4 & 47,3 & 45,8 & 45,3 \\
\hline Bengkulu & 51,3 & 47,9 & 46,2 & 44,9 & 44,3 & 44,5 \\
\hline Lampung & 51,1 & 49,5 & 48,6 & 47,3 & 45,6 & 45,3 \\
\hline Kep.Bangka Belitung & 48,6 & 46,2 & 44,9 & 44,3 & 43,3 & 43,1 \\
\hline Kepulauan Riau & 46,8 & 49,7 & 46,4 & 41,8 & 38,1 & 37,9 \\
\hline DKI Jakarta & 37,4 & 39,9 & 42,0 & 42,2 & 40,1 & 39,5 \\
\hline Jawa Barat & 49,9 & 47,7 & 46,4 & 46,4 & 46,2 & 46,6 \\
\hline Jawa Tengah & 49,9 & 48,1 & 47,7 & 48,4 & 49,9 & 51,7 \\
\hline DI Yogyakarta & 45,8 & 44,9 & 45,6 & 46,8 & 47,7 & 48,4 \\
\hline Jawa Timur & 46,2 & 44,3 & 43,9 & 44,3 & 46,2 & 48,4 \\
\hline Banten & 48,6 & 46,4 & 45,3 & 43,9 & 41,8 & 41,0 \\
\hline Bali & 47,3 & 45,6 & 43,3 & 42,2 & 43,3 & 45,8 \\
\hline NTB & 55,8 & 53,8 & 52,2 & 50,2 & 48,6 & 48,1 \\
\hline N T T & 70,6 & 66,7 & 63,4 & 62,1 & 61,6 & 61,6 \\
\hline Kalimantan Barat & 52,7 & 50,8 & 49,7 & 48,8 & 47,3 & 46,6 \\
\hline Kalimantan Tengah & 50,4 & 46,2 & 43,3 & 41,4 & 40,3 & 39,9 \\
\hline Kalimantan Selatan & 49,3 & 48,6 & 47,7 & 46,2 & 44,7 & 44,7 \\
\hline Kalimantan Timur & 48,6 & 46,2 & 44,5 & 43,7 & 43,1 & 43,5 \\
\hline Sulawesi Utara & 47,9 & 46,6 & 46,4 & 46,8 & 47,3 & 48,4 \\
\hline Sulawesi Tengah & 52,7 & 50,6 & 49,7 & 49,5 & 48,6 & 48,6 \\
\hline Sulawesi Selatan & 56,0 & 52,9 & 51,3 & 50,4 & 49,5 & 49,7 \\
\hline Sulawesi Tenggara & 63,4 & 60,5 & 58,0 & 54,6 & 52,7 & 51,5 \\
\hline Gorontalo & 51,7 & 48,6 & 47,5 & 47,7 & 47,7 & 47,9 \\
\hline Sulawesi Barat & 60,5 & 56,0 & 53,8 & 52,7 & 51,5 & 51,1 \\
\hline Maluku & 63,1 & 59,7 & 58,2 & 57,5 & 55,8 & 54,3 \\
\hline Maluku Utara & 61,3 & 58,5 & 56,0 & 53,4 & 51,5 & 50,8 \\
\hline Papua Barat & 53,6 & 49,9 & 47,1 & 45,3 & 44,3 & 43,7 \\
\hline & & & & &
\end{tabular}




\begin{tabular}{|l|c|c|c|c|c|c|}
\hline Papua & 53,8 & 47,5 & 43,7 & 42,0 & 41,6 & 42,2 \\
\hline INDONESIA & 50,5 & 48,6 & 47,7 & 47,2 & 46,9 & 47,3 \\
\hline
\end{tabular}

Sumber: BPS Indonesia

Dependency Ratio Indonesia sejak 1930 hingga 2015 menunjukkan kecenderungan semakin kecil. Hal ini menunjukkan bahwa dependency ratio yang kecil berarti beban ketergantungan penduduk usia produktif kepada penduduk produktif semakin rendah. Data Badan Pusat Statistik (BPS) Indonesia 2010 menunjukkan dependency ratio Indonesia sebesar 50,5. Sementara pada 2015 dependency ratio memiliki angka lebih kecil yaitu 48,6. Kecenderungan dependency ratio yang semakin kecil ini akan berlanjut hingga 2030, dan menciptakan Bonus Demografi bagi indonesia. Sementara itu diperkirakan setelah 2030 kecenderungan dependency ratio akan naik kembali karena jumlah lansia meningkat.

Melimpahnya jumlah penduduk muda di berbagai wilayah provinsi Indonesia telah menciptakan Bonus Demografi. Bonus Demografi di beberapa provinsi di Indonesia tersebut dapat dilihat dengan parameter dependency ratio yang cukup rendah, yaitu mencapai di bawah 45. Yang berarti bahwa dalam setiap 100 penduduk usia produktif (15-64 tahun) hanya menanggung sekitar 45 penduduk tidak produktif (0-14 dan 65 tahun ke atas). Perhatikan data dependency ratio menurut provinsi di Indonesia pada tabel 1 di atas.

Bonus Demografi sebenarnya telah dialami oleh beberapa provinsi di Indonesia sejak 2010. Beberapa provinsi itu seperti Jakarta, Yogyakarta, Jawa Timur, dan Kepulauan Riau. Berdasarkan tabel 1, menunjukkan bahwa beban ketergantungan di empat provinsi berada pada angka 46 dan 45 . Beban ketergantungan yang cukup rendah ini telah menciptakan jendela peluang untuk peningkatan pertumbuhan ekonomi di wilayah yang bersangkutan.

Bonus Demografi yang terjadi pada 2020 hingga 2035 yang harus benarbenar dimanfaatkan oleh pemerintah. Kesiapan pemerintah dalam menghadapi Bonus
Demografi tentu mendatangkan keuntungan yang besar. Dengan Bonus Demografi berarti Indonesia yang mendapati kondisi di mana jumlah angkatan kerja yang melimpah-ruah. Angkatan kerja dengan jumlah yang besar tersebut jika dapat dikelola dengan baik yang akan mendorong kemajuan dan pertumbuhan ekonomi negara. Kuncinya terletak pada peningkatan kualitas angkatan kerja yang berdaya saing pada pasar tenaga kerja global.

Saat ini Indonesia memiliki 67 juta anak muda berumur 10-24 tahun. Mereka yang akan menjadi pemimpin dan penggerak pembangunan Indonesia pada fase bonus Demografi 2020-2035. Jumlah anak muda yang melimpah menjadi incaran tenaga produktif negara-negara maju yang kekurangan anak muda. Sehingga bisa menjadi keuntungan yang besar jika Indonesia mampu merespons permintaan pasar tenaga kerja global (Kompas 29 November 2014, hlm 13).

Jumlah anak muda yang besar telah menjadikan Indonesia sebagai salah satu negara yang akan mendapatkan keuntungan Bonus Demografi selain India dan Tiongkok. Jumlah anak muda di dunia diperkirakan mencapai 1,8 miliar. Dari angka tersebut Indonesia menempati posisi ketiga setelah India yang memiliki jumlah anak muda 356 juta, dan Tiongkok yang memiliki jumlah anak muda 269 juta. Jumlah anak muda sangat menguntungkan jika strategi pembangunan yang memanfaatkan Bonus Demografi bisa dijalankan dengan benar. Dengan investasi yang tepat dari pemerintah, maka jutaan anak muda benar-benar menjadikan berkah Bonus Demografi. Dari hal tersebut jutaan anak muda, jika mampu dikelola dengan baik maka akan bisa mengubah masa depan Indonesia menjadi lebih baik.

Berdasarkan hasil Sensus Penduduk (SP) 2010, penduduk provinsi Indonesia tercatat sebanyak 4.846.909 jiwa dengan tingkat Laju Pertumbuhan Penduduk sebesar 1,34 persen yang terdiri dari 
2.404.377 laki-laki dan 2.442.532 perempuan, dengan sex rasio sebesar 94,44 persen. Sementara proyeksi yang dilakukan oleh BAPPENAS, BPS dan UNFPA memperlihatkan penambahan jumlah penduduk Indonesia 2010 - 2035. Dari data tersebut diproyeksikan bahwa pertumbuhan penduduk Indonesia menunjukkan laju pertumbuhan yang cenderung menurun sampai 2035.

Pada 2010 jumlah penduduk Indonesia sebesar 4.863,3 jiwa dan pada 2035 jumlah tersebut diproyeksikan akan mencapai 6.130,4 jiwa. Jika dilihat dari laju pertumbuhan, laju pertumbuhan penduduk Indonesia dari tahun ketahun diproyeksikan akan cenderung terus menurun sampai tahun 2035. Jika pada 2010 laju pertumbuhan penduduk mencapai 1,34 persen, angka ini akan sedikit menurun pada 2015 yaitu 1,33 persen. Angka laju pertumbuhan penduduk ini akan terus menurun menjadi 1,14 persen pada 2020 dan akan mencapai angka 0,54 persen pada 2035. Dari jelaskan di atas dapat dilihat pada tabel 2 dengan grafik dan piramida sebagai berikut.

Tabel 2

Proyeksi Penduduk 2010-2035

\begin{tabular}{|c|c|c|c|c|c|c|}
\hline Parameter & 2010 & 2015 & 2025 & 2025 & 2030 & 2035 \\
\hline 1 & 2 & 3 & 4 & 5 & 6 & 7 \\
\hline \multicolumn{7}{|l|}{ Penduduk } \\
\hline Laki - laki & 2409.2 & 2854.2 & 2441.6 & 2874.4 & 2981.1 & 3062.6 \\
\hline Perempuan & 2456.1 & 2612.1 & 2757.2 & 2883.3 & 2987.2 & 3067.8 \\
\hline Total & 4865.3 & 5196.3 & 5498.8 & $\mathbf{5 7 5 7 . 8}$ & 5968.3 & 6130.4 \\
\hline Laju Pertumbuhan & 1.34 & 1.33 & 1.14 & 0.92 & 0.72 & 0.54 \\
\hline \multicolumn{7}{|l|}{ Komposisi Umur } \\
\hline 0-14 & 31.1 & 30.3 & 29.2 & 27.5 & 25.7 & 24.2 \\
\hline $15-64$ & 63.4 & 64.2 & 64.6 & 65.1 & 65.9 & 66.4 \\
\hline $65+$ & 5.5 & 5.5 & 6.2 & 7.4 & 8.4 & 9.4 \\
\hline $\begin{array}{l}\text { Rasio } \\
\text { Ketergantungan (\%) }\end{array}$ & 57.7 & 55.6 & 54.8 & 53.6 & $\begin{array}{ll}51.7 \\
\end{array}$ & 50.6 \\
\hline \multicolumn{7}{|l|}{ Fertilitas/Fertility } \\
\hline TFR & 3.02 & 2.83 & 2.65 & 2.46 & 2.3 & 2.15 \\
\hline GRR & 1.5 & 1.4 & 1.3 & 1.2 & 1.1 & 1 \\
\hline NRR & 1.4 & 1.3 & 1.2 & 1.2 & 1.1 & 1 \\
\hline CBR & 23.6 & 21.6 & 19.8 & 18.1 & 16.9 & 15.9 \\
\hline Jumlah Kelahiran & 114.8 & 112.1 & 108.7 & 104.1 & 100.7 & 97.6 \\
\hline \multicolumn{7}{|l|}{ Mortalitas/Mortality } \\
\hline e0 Laki - laki/Male & 65.7 & 66.7 & 67.6 & 68.2 & 68.5 & 68.8 \\
\hline $\begin{array}{l}\text { e0 } \\
\text { Perempuan/Female }\end{array}$ & 69.6 & 70.6 & 71.5 & 72.0 & 72.4 & 72.7 \\
\hline e0 L+P/M+F & 67.6 & 68.6 & 69.5 & 70.1 & 70.4 & 70.7 \\
\hline IMR Laki - laki & 40.5 & 35.9 & 32.2 & 29.9 & 28.6 & 27.6 \\
\hline IMR Perempuan & 28.5 & 25.9 & 23.6 & 22.1 & 21.3 & 20.7 \\
\hline IMRL+P & 34.9 & 31.0 & 28.0 & 26.1 & 25.0 & 24.2 \\
\hline CDR & 8.1 & 7.6 & 7.5 & 7.8 & 8.3 & 9.0 \\
\hline
\end{tabular}


Virioner - Vol. $12 \backslash$ No. 2\April 2020: 421-438

\begin{tabular}{|l|l|l|l|l|l|l|}
\hline Jumlah Kematian & 39.4 & 39.4 & 41.1 & 44.6 & 49.5 & 55.2 \\
\hline Migrasi/Migration & & & & & & \\
\hline $\begin{array}{l}\text { Tingkat Migrasi } \\
\text { Netto }\end{array}$ & -1.6 & -1.8 & -2.0 & -2.2 & -2.3 & -2.3 \\
\hline
\end{tabular}

Sumber: BPS Indonesia

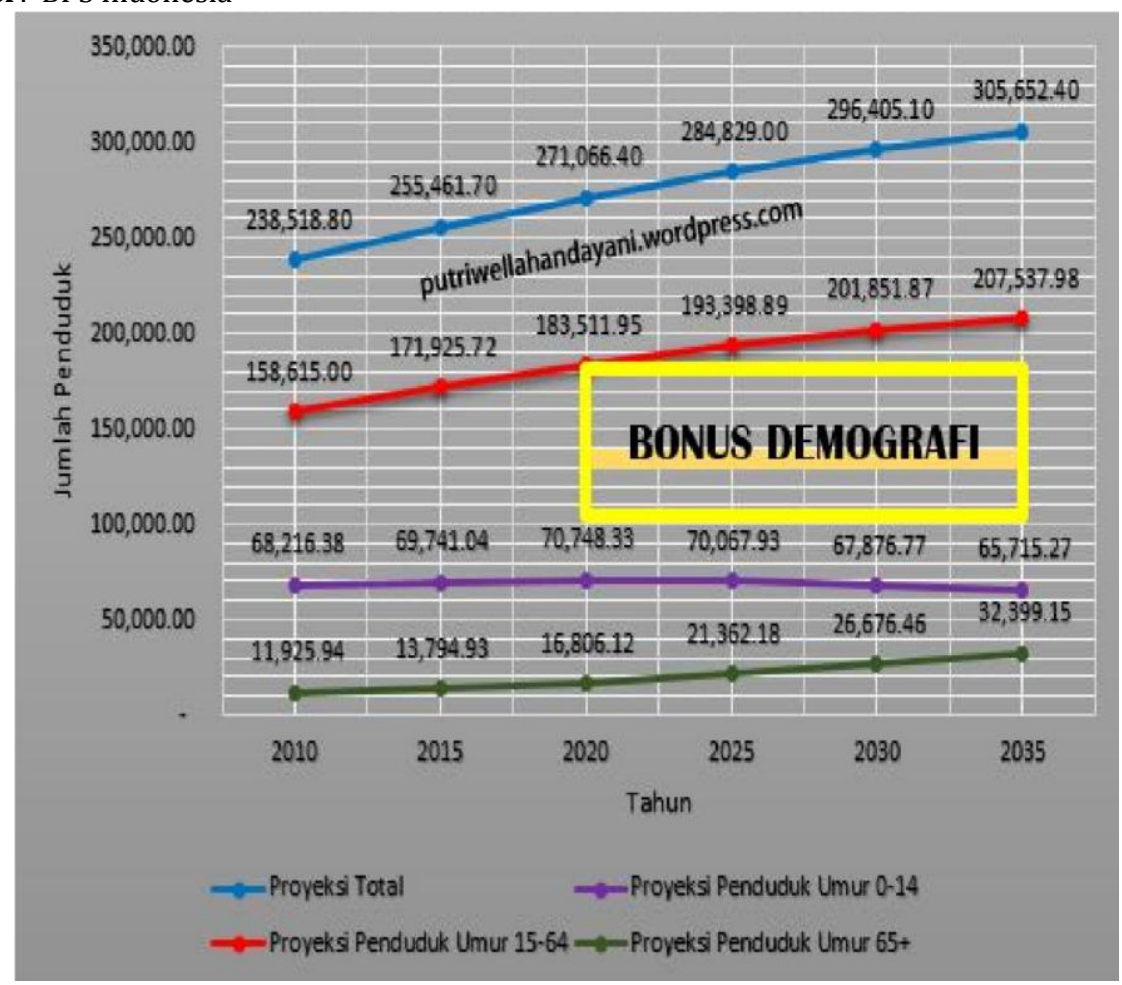

Gambar 2

Proyeksi Pendudk 2010 -2035 (Sumber: BPS Indonesia ) 


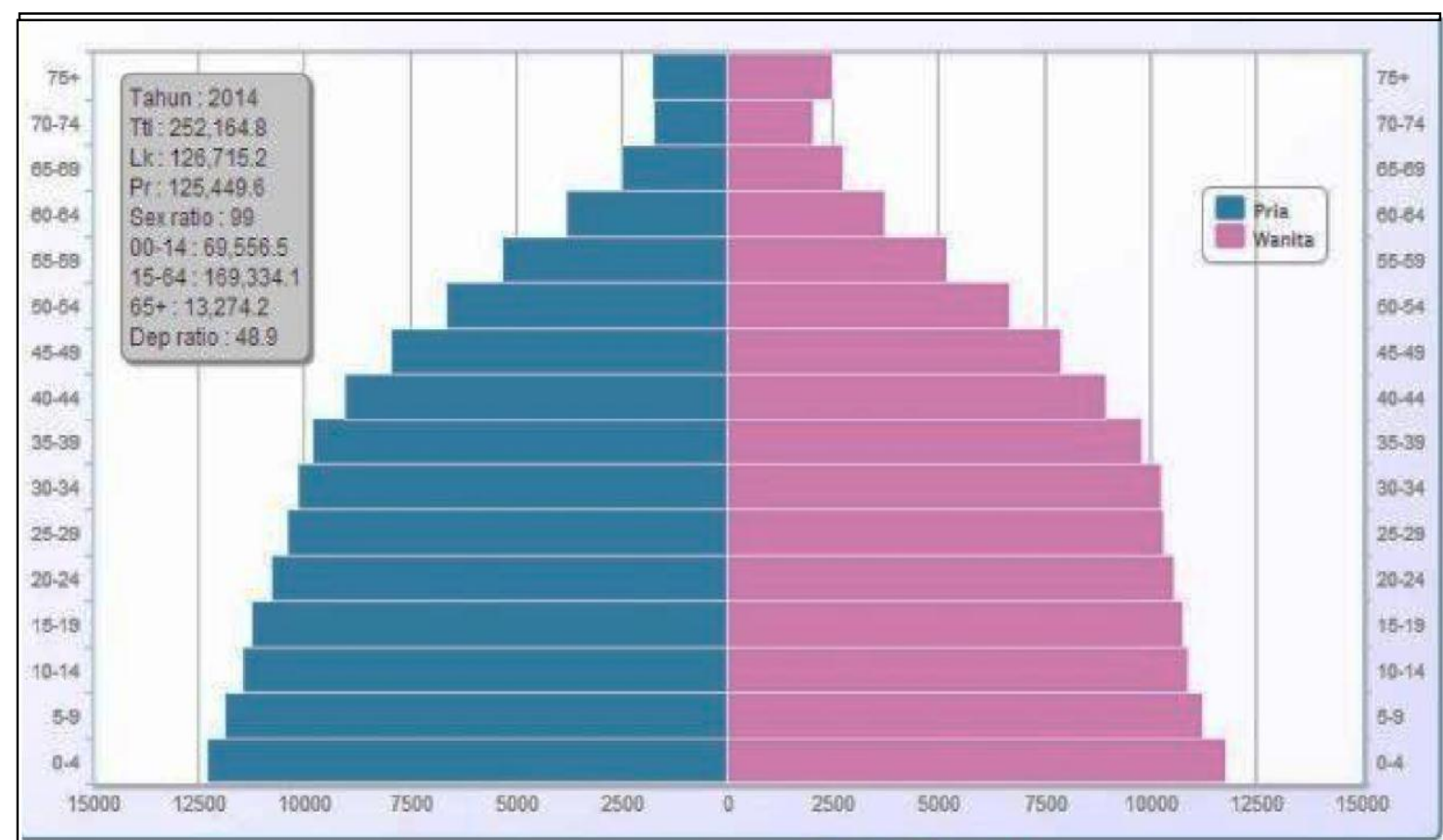

Indonesia

T 2014 . Play

Stop

Gambar 3 
Piramida Proyeksi Penduduk 2010 -2035 (000 orang)- (Sumber: BPS Indonesia

) Tabel 3. Proyeksi Penduduk Antarprovinsi 2010-2035

Sumber: BPS Indonesia

bagian tengah meskipun tidak begitu besar.

\begin{tabular}{|c|c|c|c|c|c|c|c|}
\hline \multirow{2}{*}{\multicolumn{2}{|c|}{ Prowinsi }} & \multicolumn{6}{|c|}{ tut } \\
\hline & & 2010 & 2015 & 2020 & 2025 & 2030 & 2035 \\
\hline \multicolumn{2}{|r|}{ (1) } & (2) & (3) & (4) & (5) & [6] & (7) \\
\hline 11 & Aceh & 4523,1 & 5002,0 & 5459,9 & 5870,0 & 6227,6 & $65<1,4$ \\
\hline 12 & Sumatera Litara & 13028.7 & 13937,8 & 14703,5 & 15311,2 & 15763,7 & 16073,4 \\
\hline 13 & Sumatera Earat & 4865,3 & 5196,3 & 5498,8 & 5757,8 & 5968,3 & 6130,4 \\
\hline 14 & Fiau & 55749 & 6344,4 & 7128,3 & 7898,5 & $8,643,3$ & 9363,0 \\
\hline 15 & Jambl & 3107.6 & 342,1 & 3677,9 & 3926,6 & 4142,3 & 4322,9 \\
\hline 16 & Sumatera Selatan & 7481,6 & 8052,3 & 8567,9 & 9000,4 & 9345,2 & 9610,7 \\
\hline 17 & Bengkulu & 1722,1 & 1874,9 & 2019,8 & 2150,5 & 2264,3 & 2360,6 \\
\hline 18 & Lampung & 76340 & 8117,3 & 8521,2 & 8824,6 & 9026,2 & 9136,1 \\
\hline 19 & Kep. Bangica Beltung & 12302 & 1372,8 & 1517,6 & 1657,5 & 1788,9 & $1911, \mathrm{D}$ \\
\hline \multirow[t]{2}{*}{21} & Kepulauan Flau & 16928 & 1973,0 & 2242,2 & 2501,5 & 2768,5 & 3050,5 \\
\hline & Pulau sumatera & 50860,3 & 55272,9 & 59357,1 & 62898,6 & $65,958,3$ & 68500,0 \\
\hline 31 & DKI Jakarta & 96404 & 10177,9 & $106<5,0$ & 11034,0 & 11310,0 & 11459,6 \\
\hline 32 & Jawa Barat & 43227.1 & 46709,6 & 49935,7 & 52785.7 & 55193,8 & 57137,3 \\
\hline 33 & Jawa Tengah & 324439 & 33774,1 & $349<0,1$ & 35958,6 & 36751,7 & 37219,4 \\
\hline 34 & Del Yogyaicarta & 3467,5 & 3679,2 & 3882,3 & 4054,6 & 4220,2 & 4348,5 \\
\hline 35 & Jawa Timur & 37565.8 & 38847,6 & 39886,3 & $406<6,1$ & 41077,3 & 41127,7 \\
\hline \multirow[t]{2}{*}{36} & Bamen & 10688.6 & 11955,2 & 13160,5 & 14249,0 & 15201,8 & 16033,1 \\
\hline & Pulau Jawa & 137033,3 & 145143,6 & 152449,9 & 158758,0 & 163754,8 & 167325,6 \\
\hline 51 & Ball & 3907,4 & 4152,8 & 4360,8 & 4586,0 & 4765,4 & 4912,4 \\
\hline 52 & NTE & 4.516 .1 & 4835,6 & 5125,6 & 5375,6 & 5583,8 & 5754,2 \\
\hline \multirow[t]{2}{*}{53} & NTT & 4706,2 & 5120,1 & 5541,4 & 5970,8 & 6. 402,2 & 6829,1 \\
\hline & Ball dan Kep. Nusa Tenggara & 13129,7 & 14108,5 & 15047,8 & 15932,4 & 16751,4 & 17495,7 \\
\hline 61 & Kallmantan Barat & 4411,4 & 4789,6 & 5134,6 & 5432,6 & 5679,2 & 5878,1 \\
\hline 62 & Kallmantan Tengah & 2220.8 & 2495,0 & 2769,2 & 3031,0 & 3. 273,6 & 3494,5 \\
\hline 63 & Kallmantan Selatan & 3642,6 & 3989,8 & 4304,0 & 4578,3 & 4814,2 & 5016,3 \\
\hline \multirow[t]{2}{*}{64} & Kallmantan TImur & $3.576,1$ & 4058,6 & 4561,7 & $50 \leq 0,7$ & 5497,0 & 5929,2 \\
\hline & Pulau Kallmantan & 13850,9 & 15343,0 & 16759,7 & 18082,6 & 19264,0 & 20318,1 \\
\hline 71 & Sulawesl Utara & 2277.7 & 2412,1 & 2528,8 & 2624,3 & 2696,1 & 2743,7 \\
\hline 72 & Sulawesl Tengah & 26460 & 2876,7 & 3097,0 & 3299,5 & 3480,6 & 3640,8 \\
\hline 73 & Sulawesl Selatan & 8060,4 & 8520,3 & 8928,0 & 9265,5 & 9521,7 & 9696,0 \\
\hline 74 & Sulawesl Tenggara & 2243.6 & 2499,5 & 2755,6 & 3003,0 & 3. 237,7 & 3458,1 \\
\hline 75 & Gorontalo & 1044,8 & 1133,2 & 1219,6 & 1299,7 & 1370,2 & 1430,1 \\
\hline \multirow[t]{2}{*}{76} & Sulawesl Barat & 1164.6 & 1282,2 & 1405,0 & 1527,8 & 1647,2 & 1763,3 \\
\hline & Pulau Sulaweal & 17437.1 & 18 724,0 & 19984,0 & 21019,8 & 21953,5 & 22732,0 \\
\hline \multirow{3}{*}{$\begin{array}{l}81 \\
82\end{array}$} & Maluku & 1541,9 & 1686,5 & 1831,9 & 1972,7 & 2104,2 & 2227,8 \\
\hline & Maluku Utara & 1043,3 & 1162,3 & 1278,8 & 1391,0 & 1499,4 & 1603,6 \\
\hline & Kep. Maluku & 2585,2 & 2848,8 & 3110,7 & 3.363 .7 & 3503,6 & $3 \approx s 1,4$ \\
\hline \multirow{4}{*}{$\begin{array}{l}91 \\
94\end{array}$} & Papua Earat: & 765,3 & 871,5 & 981,8 & 1092,2 & 1200,1 & 1305,0 \\
\hline & Рариа & 28570 & 3149,4 & 3435,4 & 3701,7 & 3939,4 & $41 \angle 4,6$ \\
\hline & Pulau Papua & 3622,3 & 4020,9 & 4417,2 & 4793,9 & 5. 139,5 & 5449,6 \\
\hline & Indoneal: & $516 ; 8$ & 55461,7 & 71066,4 & $34 \approx 29,0$ & 96405,1 & $905,652,4$ \\
\hline
\end{tabular}

Berdasarkan proyeksi penduduk menurut struktur umur, jumlah penduduk usia produktif Indonesia masih belum lebih besar jika dibandingkan dengan penduduk usia nonproduktif. Hal ini dapat dilihat dari bentuk piramida penduduk yang cenderung masih mengerucut ke atas. Akan tetapi pada periode 2030 dan 2035, piramida mulai memperlihatkan kecenderungan untuk mengembang di
Hal ini mengindikasikan bahwa prediksi pada periode tersebut jumlah penduduk usia produktif mulai meningkat sehingga angka dependency ratio makin kecil. Meskipun belum sepenuhnya akan mendapatkan Bonus Demografi, ini memberikan peluang bagi Indonesia untuk untuk menciptakan pertumbuhan ekonomi yang lebih baik. Indonesia perlu merumuskan langkah-langkah yang tepat 
untuk meningkatkan kualitas sumber daya manusia terutama di bidang pendidikan dan kesehatan. Di samping itu, perlu adanya percepatan di sisi ketenagakerjaan berupa penciptaan lapangan pekerjaan.

\section{Transisi Demografi Indonesia}

Revolusi mortalitas di Indonesia yang merupakan revolusi demografi pertama di Indonesia terjadi sekitar tahun 1950an. Dimulai dari adanya penurunan angka kematian akibat berbagai penemuan obatobatan antibiotika dan intervensi kesehatan di negara maju. Indonesia tidak perlu lagi menciptakan obat-obatan modern, tetapi langsung mengadopsi teknologi kedokteran modern seperti imunisasi dan antibiotika, tanpa menunggu kemajuan perekonomian. Namun demikian, kondisi tersebut belum diikuti oleh penurunan fertilitas, sehingga terjadi ledakan bayi di Indonesia pada sekitar 1950-1970-an.

Transisi demografi di Indonesia yang ditandai dengan penurunan angka kematian bayi dari 140 per 1.000 kelahiran hidup pada 1971 menjadi 35 pada 2000. Sedangkan angka fertilitas menurun dari 5,6 pada 1961 menjadi hanya 2,6 pada 2007. Artinya, jumlah anak yang dimiliki oleh setiap perempuan Indonesia hingga akhir usia reproduksinya turun dari sekitar 5 hingga 6 anak, menjadi hanya 2 hingga 3 anak. Sebagaimana telah disebutkan di atas, transisi demografi di Indonesia terjadi karena adanya program nasional keluarga berencana dengan penanaman paradigma dua anak cukup untuk mencapai keluarga kecil bahagia dan sejahtera. Pada masa itu penyediaan kontrasepsi murah diperluas, pelayanan kontrasepsi mencapai hingga ke pelosok perdesaan. Suriastini (1995) mengatakan bahwa terdapat 72,8 persen bayi tercegah kelahirannya dalam periode 19811987 sebagai dampak dari pengaturan kelahiran dan penundaan usia perkawinan. Untuk daerah Jawa dan Bali sumbangan pengaturan kelahiran meningkat dari 54,6 persen pada 19721976 menjadi 75,25 persen pada 19821987.
Di sektor kesehatan, program kesehatan makin ditingkatkan dengan pembangunan fasilitas Puskesmas untuk mendekatkan masyarakat pada fasilitas kesehatan murah, program perbaikan gizi untuk ibu, bayi dan balita serta imunisasi bagi bayi dan ibunya dalam upaya menurunkan angka kematian bayi.

Berbeda dengan negara-negara maju, transisi demografi yang terjadi di Indonesia, tidak diawali dengan pembangunan ekonomi, industrialisasi dan modernisasi. Indonesia berhasil mengalami transisi lebih cepat karena intervensi di bidang kesehatan dan pengaturan jumlah anggota keluarga melalui program keluarga berencana yang berjalan paralel dengan pembangunan di bidang ekonomi. Suriastini (1995) memperkirakan bahwa akhir masa transisi demografi akan terjadi pada 2005. Pada tersebut diperkirakan, angka harapan hidup mencapai lebih dari 65 tahun, angka kelahiran (TFR) mendekati 2 dan NRR (Net Reproduction Rate) sebesar $1 . \quad$ Periode 1990-1995, Indonesia berada pada tahap transisi yang tergolong labil, tepatnya pada tahap perkembangan akhir (late expanding stage). Dengan usia angka harapan hidup 62,7 tahun dan TFR 3,91, Indonesia telah berada di tahap ketiga transisi demografi (Mantra, 2000). Dengan demikian dari sejak tahun tersebut di atas sampai sekarang bangsa Indonesia mendapatkan Bonus Demografi yang harus dipersiapkan dengan sebaik-baiknya sesuai nawacita atau visi dan misi Presiden Republik Indonesia.

\section{Hambatan Bonus Demografi: Kemiskinan}

Kemiskinan merupakan kondisi yang tidak dapat terpenuhinya kebutuhan hidup setiap orang secara wajar. Sajogjo dalam Soekartawi:1996 mendefinisikan golongan miskin bahwa beras sebagai patokan untuk masyarakat perkotaan yang setara kurang dari setara $420 \mathrm{~kg}$ beras sebab beras menjadi bahan makanan pokok masyarakat Indonesia, dan Soekartawi juga 
mendefinisikan bahwa 'miskin' adalah mempunyai keterbatasan penghasilan, pemikiran, keterampilan, pendidikan, penghayatan kesusilaan, penghayatan keagamaan, kesehatan, perumahan, hubungan sosial dalam keluarga, hubungan sosial dalam lingkungan sekitarnya, dan hubungan sosial dalam masyarakat yang lebih sosial.

Sedangkan Bappenas (2002, dalam Lincolin Arsyad), mendefinisikan kemiskinan sebagai suatu situasi atau kondisi yang dialami seseorang atau kelompok orang yang tidak mampu menyelenggarakan hidupnya sampai suatu taraf yang dianggap manusiasi. Selanjutnya Lincolin Arsyad menjelaskan, masyarakat miskin selalu berada pada kondisi ketidakberdayaan atau ketidakmampuan mereka dalam memenuhi kebutuhan dasar, yaitu ketidakmampuan dalam (1) melakukan kegiatan usaha produktif; (2) menjangkau akses sumber daya sosialekonomi; (3) menentukan nasibnya sendiri dan senantiasa mendapatkan perlakuan diskriminatif; dan (4) membebaskan diri dari mental dan budaya miskin serta senantiasa mempunyai martabat dan harga diri yang rendah.

Perserikatan Bangsa-Bangsa (PBB) dalam "The Millenium Report," mendefinisikan kemiskinan (poverty) sebagai "this minimum level and the poor constituted the actual number of people whose income or calorie intake are less than this" dijelaskan pula bahwa dengan terinspirasinya pendapat Amartya Sea, pemenang Hadiah Nobel 1999, bahwa:

"The United Nations Development Programme (UNDP) introduced measures for progress and for deprivation that focus on poverty from a human development perspective. It now views poverty as a denial of choices and opportunities for living a tolerable life. The human poverty index (HPI) constructed for each country provides a country by country picture of deprivation in terms longevity, education and economic factors."

\section{Faktor Penentu Keberhasilan Bonus Demografi}

Bonus Demografi dapat mendatangkan keuntungan yang besar bagi Indonesia. Dengan persiapan yang baik dan investasi yang tepat, Bonus Demografi bisa mengubah masa depan Indonesia menjadi lebih sejahtera dan maju. Namun keberhasilan dalam memanfaatkan Bonus Demografi sangat dipengaruhi oleh empat faktor utama yaitu 1) kualitas pendidikan, 2) kualitas kesehatan, 3) ketersediaan lapangan kerja, dan konsistensi penurunan angka kelahiran melalui program Keluarga Berencana.

Pada fase Bonus Demografi jumlah anak muda sangat besar sebagai kelompok produktif yang telah memasuki usia kerja. Sehingga pengelolaan ketenagakerjaan yang baik, menjadi pekerjaan rumah yang harus dilakukan oleh pemerintah. Pengelolaan ketenagakerjaan yang baik dengan mempersiapkan angkatan kerja yang berkualitas, akan menentukan keberhasilan pemanfaatan Bonus Demografi. Untuk itu dalam mempersiapkan angkatan kerja yang berkualitas haruslah dilihat dari aspek kualitas pendidikan, kualitas kesehatan dan kecukupan gizi.

\section{Memanfaatkan Bonus Demografi}

Bonus Demografi merupakan kesempatan emas bagi suatu bangsa jika mampu dimanfaatkan dengan sebaik-baiknya. Namun pertanyaannya, apakah Indonesia siap memanfaatkan jendela kesempatan tersebut untuk memajukan bangsa?. Tentu bukan hal yang mudah untuk memanfaatkan bonus tersebut agar tidak menjadi peluang yang siasia atau bahkan menjadi suatu malapetaka bagi bangsa Indonesia. Seperti yang diungkapkan Adioetomo dalam Cicih (2007:11) bahwa terbukanya the window of opportunity yang menyediakan kondisi ideal untuk meningkatkan produktivitas ini, harus 
dimanfaatkan sebaik-baiknya bagi pemerintah suatu negara apabila ingin meningkatkan kesejahteraan penduduknya. Oleh karena itu, diperlukan berbagai upaya untuk memanfaatkan kesempatan tersebut. Satu hal yang paling mendasar yakni dengan meningkatkan kualitas sumber daya manusia agar mempunyai keterampilan yang berkualitas dan mampu terserap dalam dunia kerja.

Untuk menyambut datangnya Bonus Demografi, perlu adanya persiapanpersiapan yang matang agar pemanfaatannya optimal dan hasilnya juga maksimal. Menurut Bloom, Canning, \& Sevilla (2003) dalam Cicih (2007:11) menjelaskan bahwa dalam rangka mewujudkan Bonus Demografi ada tiga mekanisme penting yaitu: pasokan tenaga kerja (labour supply), tabungan (savings), dan sumber daya manusia (human capital). Bonus Demografi akan termanfaatkan dengan baik jika pertumbuhan penduduk usia kerja yang merupakan pasokan tenaga kerja mendapatkan pekerjaan yang produktif, dan kemudian bisa menabung untuk diinvestasikan terhadap bangsa sehingga memicu pertumbuhan ekonomi serta meningkatkan kesejahteraan. Sedangkan, menurut pernyataan yang disampaikan dalam warta kependudukan (2013) bahwa, syarat agar Bonus Demografi dapat dimanfaatkan dengan baik adalah dengan mempersiapkannya sejak perencanaan sampai dengan implementasinya di tingkat lapangan. Persiapan ini antara lain melalui:

1. Peningkatan pelayanan kesehatan masyarakat;

2. Peningkatan kualitas dan kuantitas pendidikan;

3. Pengendalian jumlah penduduk;

4. Kebijakan ekonomi yang mendukung fleksibilitas tenaga kerja dan pasar,keterbukaan perdagangan dan saving nasional.

Dengan demikian, Bonus Demografi menjadi kesempatan besar bagi bangsa
Indonesia yang mempunyai penduduk usia produktif diimbangi dengan ketersediaan lapangan pekerjaan sehingga penduduk usia produktif yang dituntut lebih potensial dan aktual. Sehingga hal tersebut menjadi tugas besar bagi bangsa Indonesia untuk mempersiapkan adanya Bonus Demografi yang tidak sia-sia untuk kemajuan bangsa Indonesia.

\section{SIMPULAN}

Berdasarkan penjelasan di atas, maka penulis dapat menyimpulkan bahwa Bonus Demografi yang diperoleh bangsa Indonesia pada 2020-2035 mendatang, merupakan masa transisi di mana terjadi penurunan fertilitas dalam jangka panjang yang mampu menyebabkan perubahan struktur kependudukan, terutama pada peningkatan terhadap penduduk usia produktif. Peningkatan penduduk usia produktif ini mampu menurunkan angka ketergantungan bagi penduduk usia nonproduktif, sehingga dapat memberikan keuntungan ekonomis dalam rangka meningkatkan pertumbuhan ekonomi dan kesejahteraan bangsa

Indonesia. Dengan demikian apabila bangsa Indonesia kalau tidak mau kehilangan peluang emas tersebut, maka perlu mempersiapkan sumber daya manusia yang berkualitas sejak sekarang, sehingga adanya momentum Bonus Demografi dapat benarbenar bermakna yang mampu dimanfaatkan dengan baik, dan nawacita Presiden Republik Indonesia bisa tercapai.

Peran pendidikan dalam pemanfaatan Bonus Demografi, sangat penting dalam peningkatan kualitas sumber daya manusia untuk mengembangkan potensi manusia secara optimal karena pendidikan itu sendiri merupakan investasi bagi sumber daya manusia pada masa depan. Selain pendidikan, kesehatan juga harus diperhatikan karena kesehatan merupakan salah satu aspek kualitas penduduk yang sangat penting. Sebagai modal manusia dalam peningkatan sumber daya manusia 
yang berkualitas yaitu pendidikan dan kesehatan penduduk usia produktif, secara tidak langsung bangsa Indonesia siap untuk Bonus Demografi dalam rangka memajukan bangsa. Karena dalam perencanaan pembangunan yang berwawasan kependudukan, akan menciptakan kesejahteraan bagi penduduk.

Oleh karena itu, Bonus Demografi berperan untuk mengukur kemampuan bangsa Indonesia dalam memanfaatkan Bonus Demografi, untuk memajukan bangsa, yang dimaksud di sini adalah jika bangsa Indonesia berhasil memanfaatkan adanya Bonus Demografi dengan baik, maka akan dapat membawa Indonesia lebih maju pesat karena peningkatan perekonomian yang signifikan seperti negara-negara tetangga yang telah berhasil dalam hal pemanfaatannya dalam jendela kesempatan tersebut.

Namun, dengan demikian bangsa Indonesia harus mempersiapkan perencanaan dan pemanfaatan Bonus Demografi dengan baik, sedangkan bangsa Indonesia tidak mempersiapkan hal tersebut, maka bisa terjadi bencana bagi bangsa Indonesia. Sebab, sesudah itu rasio ketergantungan bangsa Indonesia akan meningkat lagi dengan peningkatan penduduk usia tua.

\section{SARAN}

Dari pembahasan tersebut Bonus Demografi sebagai barometer kemajuan bangsa Indonesia. Penulis menyajikan saran sebagai berikut.

\section{Bagi Pemerintah}

Dalam rangka menyambut datangnya Bonus Demografi, pemerintah perlu berkonsistensi terhadap kebijakan kependudukan dengan perspektif jangka panjang dan berkesinambungan. Selain itu, pemerintah mampu mempersiapkan perencanaan pembangunan yang berwawasan kependudukan jika ingin meningkatkan kesejahteraan masyarakatnya. Dalam hal penyediaan lapangan pekerjaan yang produktif, peningkatan kualitas modal manusia tanpa melihat perbedaan gender, karena mengingat tingginya populasi penduduk usia produktif yang akan menanggung penduduk nonproduktif yang lebih sedikit populasinya.

\section{Bagi Pengusaha atau Perusahaan}

Perusahaan atau pengusaha diharapkan mampu mengembangkan usaha yang dijalankan dengan membuka lapangan pekerjaan baru sehingga memunculkan kesempatan kerja pagi penduduk usia produktif mendatang.

\section{Bagi Masyarakat}

Masyarakat merupakan faktor utama dalam pemanfaatan Bonus Demografi yang beperan untuk memajukan bangsa Indonesia, karena masyarakatlah sebagai objek dari perencanaan pemerintah dalam mempersiapkan untuk Bonus Demografi, sehingga masyarakat diharapkan mampu berpartisipasi aktif dalam setiap kebijakan yang dikeluarkan oleh pemerintah.

\section{DAFTAR PUSTAKA}

Adioetomo, \& Moertiningsih, S. (2005). “Bonus Demografi. Menjelaskan Hubungan

Antara Pertumbuhan Penduduk Dengan Pertumbuhan Ekonomi." Pidato Disampaikan pada Upacara Pengukuhan Jabatan Guru Besar Tetap dalam Bidang Ekonomi Kependudukan pada Fakultas Ekonomi Universitas Indonesia. Jakarta.

Adioetomo, Sri Moertiningsih. 2005. “Bonus Demografi Menjelaskan Hubungan Antara Pertumbuhan Penduduk dengan Pertumbuhan Ekonomi”. Warta Demografi. 35 (2):7-27. 
BKKBN. 2015. Banten Tahun 2015-2035. Jakarta: Direktorat Analisis Dampak Kependudukan BKKBN.

Bappenas, BPS dan UNFPA. 2013. Proyeksi Penduduk Indonesia 2015-2035. Jakarta.

BPS, 2015. Keadaan Angkatan Kerja di Indonesia 2015. Jakarta. Biro Pusat Statistik

2015. Produk Domestik Regional Bruto Indonesia Menurut Lapangan Usaha.

Padang. Biro Pusat Statistik Provinsi Indonesia

2015. Survei Sosial Ekonomi Nasional. Jakarta. Biro Pusat Statistik

Djojohadikusumo, s. (1991). Perkembangan Pemikiran Ekonomi. Jakarta:Yayasan Obor Indonesia.

Chotib. 2007. Menyiapkan Tenaga Kerja yang Berkualitas Menyambut Jendela Kesempatan. Warta Demografi. 37

(1):51-63.

Cicih, Lilis Heri Mis. 2007. Memanfaatkan Jendela Kesempatan. Warta Demografi. 37 (1):614

Cicih, Lilis Heri Mis. 2007. Peningkatan Kualitas Kesehatan Penduduk dalam Rangka Menyongsong Jendela Kesempatan. Warta Demografi. 37 (1):2640.

Kominfo. 2015. Siapa Mau Bonus? Peluang Demografi Indonesia. Jakarta: Kominfo.

Laksono, Agung H. R. 2013. Sambutan Menteri Koordinator Bidang Kesejahteraan Rakyat pada Seminar Internasional Mengoptimalkan Bonus Demografi untuk Kemajuan Bangsa dan Kesejahteraan Penduduk. Diambil pada 13 November 2013 dari www.bkkbn.go.id

Mardiyah, S. 2001. Konsep Indeks Pembangunan Manusia, Tiga Dimensi Pokok
Pembangunan Manusia. Surabaya: Biro Pusat Statistik Provinsi Jawa Timur.

Maryati, S. 2015. Dinamika Pengangguran Terdidik: Tanatangan Menuju Bonus Demografi di Indonesia. Journal of Economic and Economic Education, 3 (2), 124 - 136.

Prihastuti, Dewi. 2007. Peningkatan Sumber Daya Manusia Melalui Pendidikan untuk Menyongsong Bonus Demografi. Warta Demografi.37 (1):15-24.

Rusli, S., Toersilaningsih, R., Meirida, D., Kurniawan, U. K., \& Setiawan, K. D. 2015. Potensi dan Implikasi Bonus Demografi di Provinsi

Sadono, Sukirno, 2006, Ekonomi Pembangunan Proses masalah dan Dasar Kebijakan, Cetakan Ketiga, Penerbit Kencana, Jakarta

Warta Kependudukan. 2012. Tantangan dalam Mewujudkan Bonus Demografi di Provinsi Bengkulu. BKKBN. Diambil pada 13 November 2013 dari http://xa.yimg.com/kq/.../ Tagan+Menghadapi+Bonus+Demografi.do c 